\section{UDC 316.72}

Patrakov Vladimir Petrovich, philosopher, independent researcher, Republic Kazakhstan, 021500, Stepnogorsk, 3, micr. 20-40, tel.: +7 702123 1671, e-mail: bolinbrog@gmail.com

ORCID: 0000-0002-4418-4257

\section{Патраков Владимир Петрович,} філософ, незалежний дослідник, Республіка Казахстан, 021500, м. Степногорск, 3, мікр. 20-40, тел. +7 702123 1671, е-mail: bolinbrog@gmail.com

ORCID: 0000-0002-4418-4257

\section{Патраков Владимир Петрович,} философ, независимьийисследователь,Республика Казахстан, 021500, г. Степногорск, 3, микр. 20-40, тел. +7702123 1671, e-mail:bolinbrog@gmail.com

ORCID: 0000-0002-4418-4257

DOI https://doi.org/10.31618/vadnd.v1i14.112

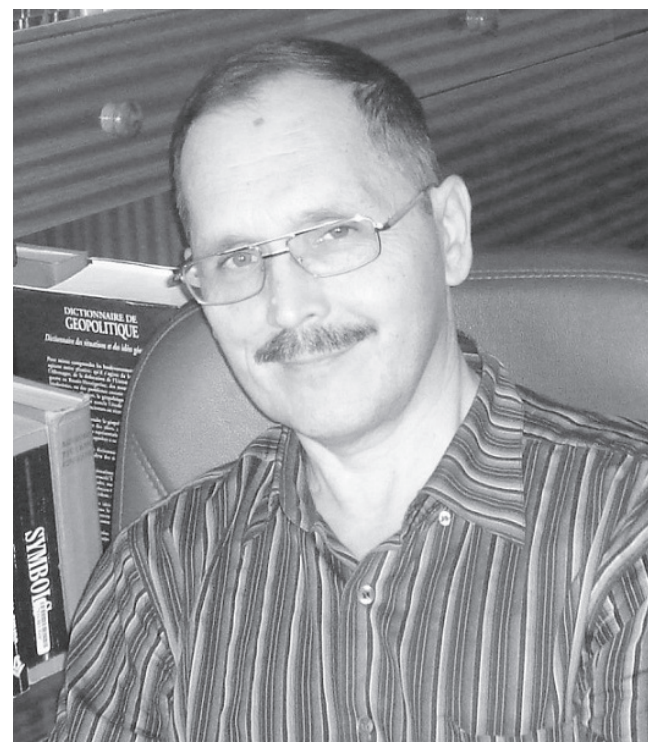

\title{
EUROPEAN GENOCODES OF NATIONAL CULTURES. IN VARIETATE CONCORDIA
}

Abstract. This paper has summarized the foundations of the author's interdisciplinary concept of national cultures genocodes (NCG), which represents synthesis of of the Hegelian doctrine about national spirits (Volksgeist), the Jung's theory of the collective unconscious, system of hexagrams of the Ancient Chinese Book of Changes and Girt Hofstede's measurements of national cultures. There are generic genes (archetypes) and species ones in the national genocodes. Generic genes are the cornerstone of 6 cultural kingdoms, and specific genes separate national cultures. All countries measured by Hofstede are divided into 6 cultural kingdoms. Kingdoms of Qian, Creative (USA, Canada, Australia, Poland and Scandinavia), Lee, Radiance (Western Europe) and Gen, Keeping Still (Japan) have an individualistic genocode. Kingdoms Zhen, Arousing (Russia, the Balkans, Greece, Turkey, Central Asia), Dui, Joyous (Africa, Latin America, Middle East) and Kun, Receptive (China, India and Southeast Asia) have a collectivist genocode. The basis of European civilization is the generic genes of the kingdoms of Lee, Qian and Zhen. The interaction between the generic and species genes of these kingdoms, their complementarity or conflict lies at the heart of alliances or wars between states. It has been shown that the greatest conflicts are observed between countries with individualistic and collectivist cultures, therefore the Balkan countries, Greece, Turkey and Russia throughout history were 
in a varying degree unfavorable relations with the Western European countries. But studying NCG will allow to minimize tension between countries, to understand a role and the place of each country in the World and in particular the European Cultural Space, to lay a way to the long-term union of peoples and states.

Keywords: genocodes of national cultures, Jungian archetypes, Hofstede's cultural dimensions theory, European civilization.

\section{ЄВРОПЕЙСЬКІ ГЕНОКОДАМИ НАЦІОНАЛЬНИХ КУЛЬТУР. IN VARIETATE CONCORDIA}

Анотація. Викладено основи авторської міждисциплінарної концепції генокодів національних культур (ГНК), яка являє собою синтез гегелевського вчення про національний дух (Volksgeist), теорії про архетипи колективного несвідомого Юнга, системи гексаграмм давньокитайського "Канона змін” та вимірювання національних культур у співавторстві соціалістичної партії Хірат Хофстеде. У національних генокодах виділяються родові гени (архетипи) і видовидні. Родові гени лежать в основі 6-ти культурних царств, а видові - в окремих національних культурах. Усі вимірені Хофстеде країни поділяються на 6 культурних царств. Царства Цянь, Творчість (США, Канада, Австралія, Польща та Скандинавія), Лі, Сяяння (Західна Європа) і Ген, Зосередження (Японія) мають індивідуалістичний генокод. А царства Чжень, Збудження (Росія, Балкани, Греція, Туреччина, Середня Азія), Дуй, Радість (Африка, Латинська Америка, Близький Схід) і Кунь, Виконання (Китай, Індія і ЮВА) - колективістський генокод. Основу європейської цивілізації утворюють родовні гени царства Лі, Цянь і Чжень. Взаємодія між родивими та видовими генами цих царств, їх комплементарність або конфлікт лежить в основі союзів між державами або війнами. Показано, що найбільші конфлікти спостерігаються між країнами з індивідуалістичною та колективістською культурами, тому Балканські країни, Греція, Туреччина та Росія протягом усієї історії знаходилися у тому чи іншому ступені напруженості відносин із Західноєвропейськими країнами. Але розуміння та вивчення генокодів національних культур дасть можливість зняти тиск і конфлікт між країнами, зрозуміти роль та місце кожної країни у світовій та, зокрема, Європейській Культуросфері, прокласти шлях до довгострокового союзу народів і держав.

Ключові слова: генокоди національних культур, архетипи Юнга, індекси Г. Хофстеде, європейська цивілізація.

\section{ЕВРОПЕЙСКИЕ ГЕНОКОДЫ НАЦИОНАЛЬНЫХ КУЛЬТУР. IN VARIETATE CONCORDIA}

Аннотация. Изложены основы авторской междисциплинарной концепции генокодов национальных культур (ГНК), которая представляет собой синтез гегелевского учения о национальном духе (Volksgeist), теории об архетипах коллективного бессознательного Юнга, системы гексаграмм древнекитайского “Канона перемен” и измерений национальных культур голландского социолога Гирта Хофстеде. В национальных генокодах выде- 
ляются родовые гены (архетипы) и видовые. Родовые гены лежат в основе 6-ти культурных царств, а видовые - отдельных национальных культур. Все измеренные Хофстеде страны делятся на 6 культурных царств. Царства Цянь, Творчество (США, Канада, Австралия, Польша и Скандинавия), Ли, Сияние (Западная Европа) и Гэнь, Сосредоточенность (Япония) имеют индивидуалистический генокод. А царства Чжэнь, Возбуждение (Россия, Балканы, Греция, Турция, Средняя Азия), Дуй, Радость (Африка, Латинская Америка, Ближний Восток) и Кунь, Исполнение (Китай, Индия и ЮВА) коллективистский генокод. Основу европейской цивилизации образуют родовые гены царства Ли, Цянь и Чжэнь. Взаимодействие между родовыми и видовыми генами этих царств, их комплементарность или конфликтность лежит в основе союзов между государствами или войн. Показано, что наибольшие конфликты наблюдаются между странами с индивидуалистической и коллективисткой культурами, поэтому Балканские страны, Греция, Турция и Россия на протяжении истории находились в той или иной степени напряженных отношениях с Западноевропейскими странами. Но понимание и изучение генокодов национальных культур позволит снять напряженность и конфликтность между странами, понять роль и место каждой страны в мировой и в частности Европейской Культуросфере, проложить путь к долгосрочному союзу народов и государств.

Ключевые слова: генокоды национальных культур, архетипы Юнга, индексы Г. Хофстеде, европейская цивилизация.

Target setting. Theories of Jung' archetypes of the collective unconscious and the regimes of imagination of Gilbert Duran have a powerful cognitive potential. But these theories have purely qualitative, semantic nature are still little used in the study of national cultures. The cognitive potential of an archetypic paradigm can be strengthen by a connection with quantitative methods. For this purpose the author suggested the concept of national cultures genocodes (NCG) in which quantitative approach (crosscultural measurements of national cultures) was combined with the system of archetypes of collective unconscious.
Analysis of basic research and publications. The foundations of the concept of NCG were set forth in the author's monograph "Geopolitics of the Book of Changes" (2015) [1] and in the article "Genocodes of National Cultures" (2016). In the book the most general approach to the concept of GNC was offered: the genocodes were considered at the level of big communities - the cultural kingdoms. Later, in the article "Genocodes of National Cultures" the concept of genocodes was applied to individual countries.

The purpose of the article. In this article the basic principles of the NCG are presented through a series of the European states. Since the NCG was 
created on the foundation of an interdisciplinary approach, the analysis of national cultures of the European countries in terms of this concept could give new results, which could not be obtained within the framework of individual social sciences.

The statement of basic materials. Basic concepts of the NCG. The theoretical precursor of the NCG is Hegel's doctrine of the natural soul and the people's spirits [3, 4]. According to Hegel, the people's spirit determines the character, mentality and values of this people and therefore lies at the heart of its history. In Hegel's system of categories the people's spirit is between the kingdom of nature and consciousness and thus coincides with the collective unconscious [5]. Recall that the concept of the unconscious was developed by Z. Freud, C. Jung and G. Durand: Freud discovered the unconscious, Jung discovered its archetypes, and Durand - the system of archetypes and regimes of their functioning (Nocturne and Diurne). In terms of the NCG, the archetypes of the national collective unconscious play a role of genes of culture, which constitute the cultural genocode of a people. This genocode lies in the foundation of the national cultural identity.

Because archetypes are closely connected with basic values of a people, studying values, we study archetypes. From the numerous of cross-cultural measurements Geert Hofstede's national culture dimensions from 6 valuable indexes is the most developed.

- The power distance index (PDI) is defined as "the extent to which the less powerful members of organizations and institutions (like the family) accept and expect that power is distributed unequally".

- Individualism vs. collectivism (IDV): This index explores the "degree to which people in a society are integrated into groups". Individualistic societies have loose ties that often only relates an individual to his/her immediate family. Its counterpart, collectivism, describes a society in which tightly-integrated relationships tie extended families and others into in-groups.

- Uncertainty avoidance index (UAI): The uncertainty avoidance index is defined as "a society's tolerance for ambiguity," in which people embrace or avert an event of something unexpected, unknown, or away from the status quo.

- Masculinity vs. femininity (MAS): In this dimension, masculinity is defined as "a preference in society for achievement, heroism, assertiveness and material rewards for success". Its counterpart represents "a preference for cooperation, modesty, caring for the weak and quality of life".

- Long-term orientation vs. shortterm orientation (LTO): This dimension associates the connection of the past with the current and future actions/challenges. A lower degree of this index (short-term) indicates that traditions are honored and kept, while steadfastness is valued. Societies with a high degree in this index (long-term) views adaptation and circumstantial, pragmatic problem-solving as a necessity.

- Indulgence vs. restraint (IND): This dimension is essentially a measure of happiness. Indulgence is defined as "a society that allows relatively free gratification of basic and natural human desires related to enjoying life and 
having fun". Its counterpart is defined as "a society that controls gratification of needs and regulates it by means of strict social norms". Indulgent societies believe themselves to be in control of their own life and emotions; restrained societies believe other factors dictate their life and emotions [6, 7].

Power distance index and Individualism vs. collectivism, according to Hofstede, considerably correlate with each other, therefore they were united by a canadian researcher Mondo Secter in one index - Individualism in Power distance (IPD) [8].

Further, we added one more index to Hofstede's indexes - Extraversion vs. introversion (EI). According to C. Jung, the Abrahamic (western) religions have an extravert orientation, and the non-Abrahamic (eastern) ones - an introvert [9]. Therefore, cultures with prevalence of the western religions (Christianity, Islam, Judaism) will be designated by an index of extraversion $(E)$, and the east religions (the Buddhism, Hinduism, etc.) - an index of introversion (I).

The next step is to arrange the culture indexes in a hierarchical order from the abstract to the concrete. Extraversion vs. introversion indexes mark space (external or internal) of development, Long term vs. short-term time, Individualism vs. collectivism in power distance - structure (subject) of development, Masculinity vs. femininity - a gender, Indulgence vs. restraint - anima (emotional processes), Uncertainty avoidance - ratio (mentality).

In more detail this scheme looks so.

1. Space. Extraversion is an active external activity, expansionism. Intro- version is the predominance of domestic policy, isolationism.

2. Time. Short-term orientation (normativity) is the past and the present. Long-term orientation (pragmatism) is the future.

3. Subject, its structure. Individualism - members of society are rather independent from each other. Collectivism - members of society are closely connected with each other.

4. Gender. Masculinity is competition, stiffness, struggle. Femininity is softness, cooperation, harmony.

5. Anima. Indulgence is emotionality, emancipation. Restraint is formalism, dryness.

6. Ratio (Mentality). Acceptance of uncertainty (openness) is situationality, spontaneity, openness to the new, unpredictability. Avoiding uncertainty (closed) is consistency, systematic, predictable.

The first three indices denote the generic, the most profound and universal archetypes of the six cultural kingdoms, and the last three - the species archetypes. Together, the generic and species indices (archetypes) denote the country (people) genocode.

These cross-cultural indices need to be combined with a system of archetypes, since only such a connection will give a holistic description of the culture of any people. And such system of archetypes of collective unconscious exists, it is called the I Ching, "Canon of changes" compiled by Chinese priestspredictors in the Shan era (around 1600 BC) [10]. Notice also that "Canon of changes" was one of sources of the Jung's concept of archetypes of collective unconscious. C. Jung considered the I Ching's symbols (64 hexagrams 
formed by six whole and discontinuous lines, yang and yin) as visual expression of the archetypes. By way of reminder, that yang denotes the masculine principle, light, hardness, energy, strength, creativity, etc., and yin - the feminine principle, darkness, softness, matter, fulfillment, etc. From this, the first lower hexagram's line corresponds to space, the second - time, the third - structure, the fourth - a gender, the fifth anima, the sixth (highest) - ratio.

Table 1 demonstrates conformity of the generic and species genes to the yin-yang symbols and Gilbert Duran's Diurne and Nocturne regimes.

\section{Correspondence of the generic and species genes with each other and with the symbols yin-yang}

\begin{tabular}{|c|c|c|}
\hline $\begin{array}{l}\text { Generic genes } \\
\text { (Kingdoms) }\end{array}$ & $\begin{array}{c}\text { Species genes } \\
\text { (Families) }\end{array}$ & Presentations \\
\hline 1. Space & 4. Gender & Space - Gender \\
\hline $\begin{array}{l}\text { - External } \\
\text { 1. Extraversion } \\
\text { yan-gene }\end{array}$ & $\begin{array}{l}\text { - Masculinity } \\
\text { 4. Masculinity } \\
\text { yang-gene }\end{array}$ & $\begin{array}{l}\text { - Yang-space: external and masculinity. Di- } \\
\text { urne } \\
\text { 1-4. Heterogeneous, light, solid. Open- } \\
\text { ness, unfolding, infiniteness. Compe- } \\
\text { tition, aggressiveness. The Abrahamic } \\
\text { religions. Search for the truth }\end{array}$ \\
\hline $\begin{array}{l}\text { - Internal } \\
\text { 1. Introversion } \\
\quad \text { yin-gene }\end{array}$ & $\begin{array}{l}\text { - Femininity } \\
\text { 4. Femininity } \\
\text { yin- gene }\end{array}$ & $\begin{array}{l}\text { - Yin-space: internal and feminine. Noc- } \\
\text { turne } \\
\text { 1-4. Homogeneous, dark, soft. Closed, } \\
\text { convolution, finiteness. Peacefulness, } \\
\text { cooperation. Eastern religions. Search } \\
\text { for harmony }\end{array}$ \\
\hline 2. Time & 5. Anima & Time - Emotions \\
\hline $\begin{array}{l}\text { - Past and Present. } \\
\text { Normativity } \\
\text { 2. Yang-gene of short- } \\
\text { term (normative) }\end{array}$ & $\begin{array}{l}\text { - "Cold" society } \\
\text { 5.Yang-gene } \\
\text { restraint }\end{array}$ & $\begin{array}{l}\text { - Yang processes: time and emotions. Di- } \\
\text { urne } \\
\text { 2-5. Short-term plans and projects, turn- } \\
\text { ing to the past, monumentalism, pride, } \\
\text { constancy, restraint, superiority, etc. }\end{array}$ \\
\hline $\begin{array}{l}\text { - Future. Pragmatism } \\
\text { 2. Yin-gene long term } \\
\text { (pragmatism) }\end{array}$ & $\begin{array}{l}\text { - "Hot" society } \\
\text { 5.Yin-gen } \\
\text { indulgence }\end{array}$ & $\begin{array}{l}\text { - Yin processes: time and emotions. Noc- } \\
\text { turne } \\
\text { 2-5. Long-term plans and projects, soft- } \\
\text { ness, sensuality, emotionality, flexibili- } \\
\text { ty, brotherhood, love, looseness, etc. }\end{array}$ \\
\hline 3. Structure & 6. Mentality & Structure - Mentality \\
\hline $\begin{array}{l}\text { - Discreteness } \\
\text { 3. Yang-gene } \\
\text { of individualism }\end{array}$ & $\begin{array}{l}\text { - Avoiding } \\
\text { uncertainty } \\
\text { 6. Yang-gene } \\
\text { of closure }\end{array}$ & $\begin{array}{l}\text { - Jan social and mental structures. Diurne } \\
\text { 3-6. Autonomy, rigidity, logic, mechanistic, } \\
\text { systematic, impenetrable. Reductio- } \\
\text { nism. A small distance of power }\end{array}$ \\
\hline $\begin{array}{l}\text { - Integrity } \\
\text { 3. Yin-gene } \\
\text { of collectivism }\end{array}$ & $\begin{array}{l}\text { - Taking } \\
\text { uncertainty } \\
\text { 6.Yin- gene } \\
\text { openness }\end{array}$ & $\begin{array}{l}\text { - Yin social and mental structures. Nocturne } \\
\text { 3-6. Cohesion, softness, spontaneity, or- } \\
\text { ganicness, continuity, permeability, } \\
\text { situability, unpredictability. Holism. } \\
\text { A great power distance }\end{array}$ \\
\hline
\end{tabular}


In Table 2, 8 trigrams of the "Canon of changes" correspond to the cultural genes. 8 trigrams by combining create 64 hexagrams, 64 genocodes of culture, which are divided into 8 groups (kingdoms). In these hexagrams consisting of 6 lines, the first trigram (lines 1, 2,3) corresponds to the generic genes, and the second trigram (lines 4, 5,6) - to the specific ones.

Two kingdoms did not coincide with the Hofstede indices. These are the kingdoms of the natural elements of Kun, Waters (World Ocean) and Xun, Air (Space). This way we get real geno- codes of 6 cultural kingdoms, formed from the generic genes.

- 111 The Global Individualistic Qian's Kingdom (Heaven, Creativity). USA, Canada, Australia, New Zealand, Ireland, Denmark, Norway, Iceland, Poland.

- 110 The Global Collectivist - the Kingdom of Dui (Lake, Joy). The countries of Latin America, Africa and the Middle East.

- 101 The European Individualistic - the Kingdom of Lee (Sun, Radiance). Western European countries.

Table 2

Trigrams. Correspondence of the generic and species genes

\begin{tabular}{|c|c|c|c|c|c|c|}
\hline Trigram & Name & Attribute & $\begin{array}{c}\text { Image in } \\
\text { Nature }\end{array}$ & Code & $\begin{array}{l}\text { Generic } \\
\text { genes } \\
(1-\text { yang, } \\
0-\text { yin) }\end{array}$ & $\begin{array}{c}\text { Species } \\
\text { genes } \\
(1-\text { yan, } \\
0-\text { yin) }\end{array}$ \\
\hline & Qian & the Creative & Heaven & 111 & $\begin{array}{l}\text { 1. Individualism } \\
\text { 1. Normativity } \\
\text { 1. Extraversion }\end{array}$ & $\begin{array}{l}\text { 1. Closedness } \\
\text { 1. Restraint } \\
\text { 1. Masculinity }\end{array}$ \\
\hline 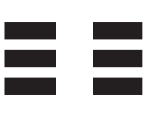 & Kun & $\begin{array}{l}\text { the Receptive, } \\
\text { Field }\end{array}$ & Earth & 000 & $\begin{array}{l}0 . \text { Collectivism } \\
0 . \text { Pragmatism } \\
0 . \text { Introversion }\end{array}$ & $\begin{array}{l}0 . \text { Openness } \\
0 . \text { Indulgence } \\
0 . \text { Femininity }\end{array}$ \\
\hline 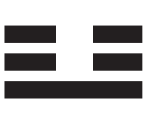 & Zhen & $\begin{array}{l}\text { the Arousing, } \\
\text { Shake }\end{array}$ & Thunder & 100 & $\begin{array}{l}0 . \text { Collectivism } \\
0 . \text { Pragmatism } \\
\text { 1. Extraversion }\end{array}$ & $\begin{array}{l}0 . \text { Openness } \\
0 . \text { Indulgence } \\
\text { 1. Masculinity }\end{array}$ \\
\hline & Gen & $\begin{array}{l}\text { Keeping Still, } \\
\text { Bound }\end{array}$ & Mountain & 001 & $\begin{array}{l}\text { 1. Individualism } \\
0 . \text { Pragmatism } \\
0 . \text { Introversion }\end{array}$ & $\begin{array}{l}\text { 1. Closeness } \\
0 . \text { Indulgence } \\
0 . \text { Femininity }\end{array}$ \\
\hline & $\mathrm{Li}$ & $\begin{array}{l}\text { the Clinging, } \\
\text { Radiance }\end{array}$ & Fire & 101 & $\begin{array}{l}\text { 1. Individualism } \\
0 . \text { Pragmatism } \\
\text { 1. Introversion }\end{array}$ & $\begin{array}{l}\text { 1. Closeness } \\
0 . \text { Indulgence } \\
\text { 1. Masculinity }\end{array}$ \\
\hline 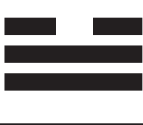 & Dui & $\begin{array}{l}\text { the Joyous, } \\
\text { Open }\end{array}$ & Lake & 110 & $\begin{array}{l}\text { 0. Collectivism } \\
\text { 1. Normative } \\
\text { 1. Introversion }\end{array}$ & $\begin{array}{l}\text { 0. Openness } \\
\text { 1. Restraint } \\
\text { 1. Masculinity }\end{array}$ \\
\hline 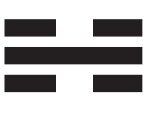 & Kan & $\begin{array}{l}\text { the Abysmal, } \\
\text { Gorge }\end{array}$ & Water & 010 & $\begin{array}{l}\text { 0. Collectivism } \\
\text { 1. Normative } \\
0 . \text { Introversion }\end{array}$ & $\begin{array}{l}0 . \text { Openness } \\
\text { 1. Restraint } \\
0 . \text { Femininity }\end{array}$ \\
\hline & Xun & $\begin{array}{l}\text { the Gentle, } \\
\text { Ground }\end{array}$ & Wind & 011 & $\begin{array}{l}\text { 1. Individualism } \\
\text { 1. Normative } \\
0 . \text { Introversion }\end{array}$ & $\begin{array}{l}\text { 1. Closeness } \\
\text { 1. Restraint } \\
\text { 0. Femininity }\end{array}$ \\
\hline
\end{tabular}


- 100 The Eurasian Collectivist - the Kingdom of Zhen (Lightning, Excitation). Russia, some countries of Eastern Europe and Central Asia.

- 000 The Asian Collectivist - the Kingdom of Kun (Earth, Execution). India, China and the countries of Southeast Asia.

- 001 The Asian Individualistic - the Kingdom of Gen (Mountain, Focus). Japan.
The genocodes of Europe. The genocodes of individual peoples and countries are formed by adding to the generic genes of the specific ones. Now consider the genocodes of Europe. Table 3 shows the formation of a combined index of Individualism in Power distance.

Table 4 lists the genocodes of the European countries. For the translation the values of the Hofstede indices

Table 3

The combined index of individualism in power distance (IPD) [7, 8]

\begin{tabular}{|c|c|c|c|c|c|}
\hline № & Country & $\begin{array}{c}\text { A } \\
\text { Power Distance } \\
\text { PDI }\end{array}$ & $\begin{array}{c}\text { B } \\
\text { Individualism } \\
\text { IDV }\end{array}$ & $\begin{array}{c}C \\
100-A\end{array}$ & $I P D=(B+C) / 2$ \\
\hline 1 & 2 & 3 & 4 & 5 & 6 \\
\hline 1 & Austria & 11 & 55 & 89 & 72 \\
\hline 2 & Belgium & 65 & 75 & 35 & 55 \\
\hline 3 & Bulgaria & 70 & 30 & 30 & 30 \\
\hline 4 & Croatia & 73 & 33 & 27 & 30 \\
\hline 5 & Czech Republic & 57 & 58 & 43 & 50,5 \\
\hline 6 & Denmark & 18 & 74 & 82 & 78 \\
\hline 7 & Estonia & 40 & 60 & 60 & 60 \\
\hline 8 & Finland & 33 & 63 & 67 & 65 \\
\hline 9 & France & 68 & 71 & 32 & 51,5 \\
\hline 10 & Germany & 35 & 67 & 65 & 66 \\
\hline 11 & Greece & 60 & 35 & 40 & 37,5 \\
\hline 12 & Hungary & 46 & 80 & 54 & 67 \\
\hline 13 & Iceland & 30 & 60 & 70 & 65 \\
\hline 14 & Irelan & 28 & 70 & 72 & 71 \\
\hline 15 & Italy & 50 & 76 & 50 & 63 \\
\hline 16 & Latvia & 44 & 70 & 56 & 63 \\
\hline 17 & Lithuania & 42 & 60 & 58 & 59 \\
\hline 18 & Luxembourg & 40 & 60 & 60 & 60 \\
\hline 19 & Malta & 56 & 59 & 44 & 51,5 \\
\hline 20 & Netherlands & 38 & 80 & 62 & 71 \\
\hline 21 & Norway & 31 & 69 & 69 & 69 \\
\hline 22 & Poland & 68 & 60 & 32 & 46 \\
\hline 23 & Portugal & 63 & 27 & 37 & 32 \\
\hline
\end{tabular}


End of table 3

\begin{tabular}{|c|l|c|c|c|c|}
\hline 1 & \multicolumn{1}{|c|}{2} & 3 & 4 & 5 & 6 \\
\hline 24 & Romania & 90 & 30 & 10 & 20 \\
\hline 25 & Russia & 93 & 39 & 7 & 23 \\
\hline 26 & Serbia & 86 & 25 & 14 & 18,5 \\
\hline 27 & Slovakia & 104 & 52 & -4 & 24 \\
\hline 28 & Slovenia & 71 & 27 & 29 & 28 \\
\hline 29 & Spain & 57 & 51 & 43 & 47 \\
\hline 30 & Sweden & 31 & 71 & 69 & 70 \\
\hline 31 & Switzerland & 34 & 68 & 66 & 67 \\
\hline 32 & Turkey & 66 & 37 & 34 & 35,5 \\
\hline 33 & United Kingdom & 35 & 89 & 65 & 77 \\
\hline
\end{tabular}

in two-valued (0-1, yin-yang) form, we calculated the average digit for each index with an interval of $+/-2$. The indices inside the interval are called transitional.

On the map Geography of the European genocodes, we see slightly simplified data 4 tables.

The semantics of genocodes, concluded in the hexagrams of the I Ching and primarily in their names, reflects the place and role of a nation in the European civilization.

The genocode of Austria and Belgium is called Radiance 101 101. It is a harmonious genocode expressing the essence of European culture.

Two leading states of Western Europe Italy and Germany (and also the Czech Republic and Hungary that at the turn of the first millennium perceived German culture) have the

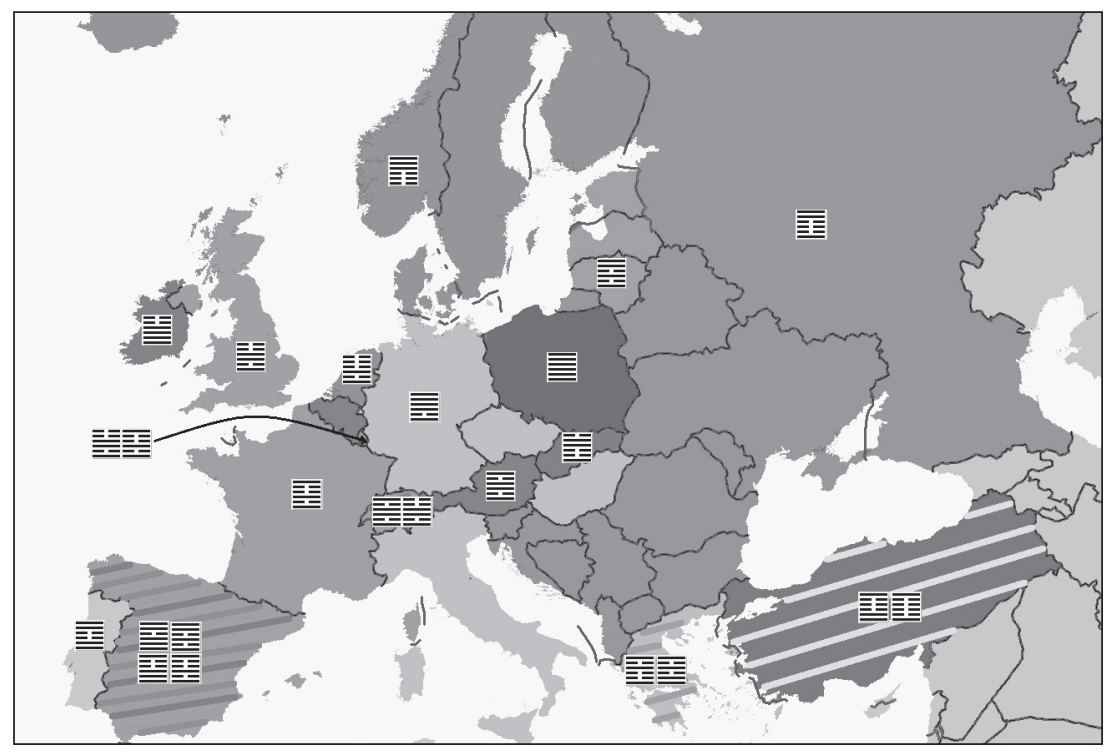

Geography of the European genocodes 
$\frac{\square}{\frac{0}{0}}$



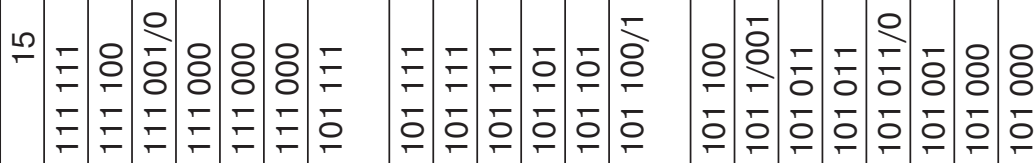

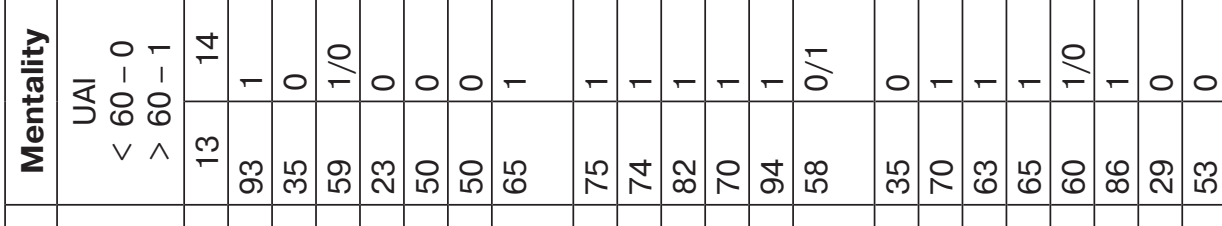

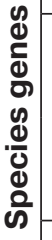



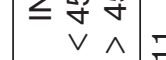







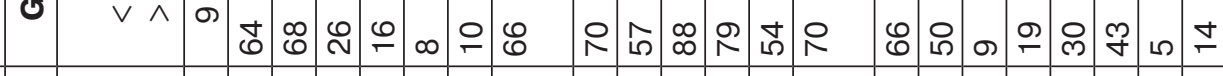





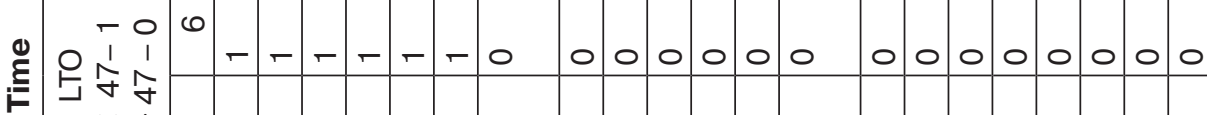

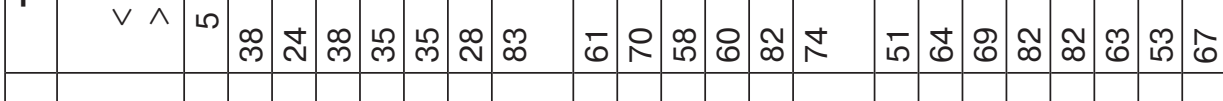

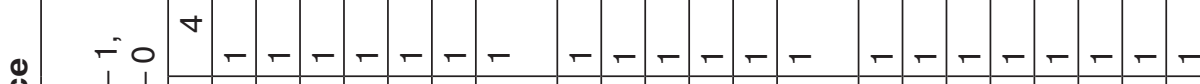

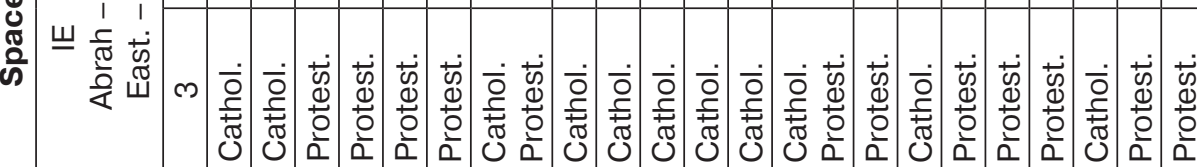

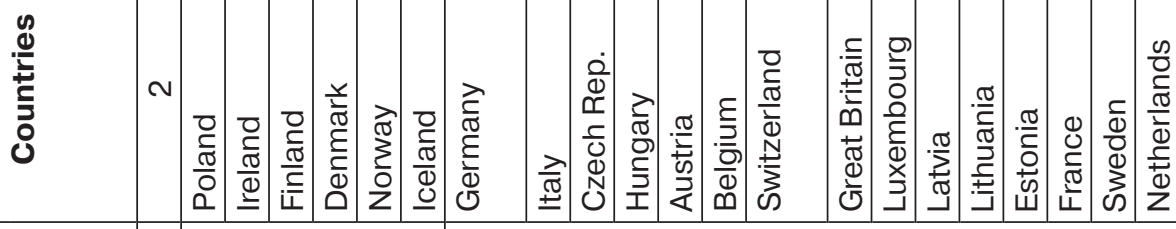








genocode Concording People 101111. This genocode differs in overwhelming prevalence of yang genes -5 , which indicates its strength and rigidity. Therefore, throughout the most part of the history Germany and Italy were fragmented into many feudal micro-states that fought endlessly among themselves. But, despite the fragmentation, Germany has always been an integrating force in Europe, first as the center of the Holy German Empire, and now - the European Union. And the Holy See of the Pope united Catholics not only in Europe, but in the whole world.

The genocode of France Adorning 101001 is harmonious ( 3 yang and 3 yin-gene) and dynamic. It adorns modern civilization with the light of social ideas, morality, and also with special grace and style. France - the birthplace of European style, fashion and etiquette.

Great Britain's genocode Abounding 101100 consists of three yang and three yin-genes. Hardness of masculinity is combined in it with openness to uncertain and unknown and condescension to the emotional party of human life. This combination made the UK the ancestor of a scientific and technological revolution, that transformed the whole world.

The Scandinavian genocode is called Peace 111 000. Therefore it is not surprising, that the Scandinavian countries win first place in the ratings of human development. Harmonious interaction between the generic yang and species yin-genes, Heaven and Earth, between the people and ruling elites allowed the Scandinavians to find the middle way reconciling all sectors of society, which was called the Scandinavian model. 
The genocode of Poland Pure yang 111111 is the hardest genocode. Its characteristics: firmness and strength (a thousand-year Polish history among struggling civilizations), fragility (endless internal conflicts and disintegrations of the country). Throughout most of its history, Poland played the role of a western shield from the eastern "barbarians". But, if the West and Russia agreed, then the need for a shield disappeared and Poland as a state disappeared too.

The Genocode of Sweden and the Netherlands is called Darkening of the Light (or Enlightenment of the Barbarians) 101000 . It is the most yin genocode of the Lee's kingdom, the kingdom of the Sun. Therefore, in cultures of Sweden, but mainly the Netherlands so many nocturnal, yin motifs. It was the Netherlands that developed a culture of euthanasia, drug consumption, tolerance to various minorities.

The Baltic countries Lithuania, Latvia and Estonia have one yang-yin genocode Household 101 011. This genocode separated the Balts from the Russian Empire and then the USSR, which in their view were barracks, hostels. They kept their european values in conditions of a collectivistic culture that was alien to them.

Luxembourg has a transitional genocode, including the female and male genes, which is called Radiance-Adorning 101 101-101 001. The function of this genocode is to connect the male German and female French cultures. Thus it is no accident that, despite its small size, Luxembourg plays an important role in European integration.

The transitional genocode of Switzerland is called Radiance-Abounding
101 101-101 100. It connects the Catholic, closed to the uncertainty of the country, with the Protestant, with their genome of openness. It is a harmonious genocode that underlies the history of the Swiss peoples, a small country in the center of Europe, which shows an example of democracy, equal rights of peoples, peaceful cooperation and sustainable development.

Genocode of Slovakia Following 100110 is at the heart of a well-integrated, stable society. In foreign policy, it means following other, more powerful neighbors. Only on the basis of this genocode, Slovaks, a small people in the center of Europe, could preserve their unique culture.

Russia and the Balkan countries (Bulgaria, Romania, Serbia, Croatia) have a single yang-yine genocode Increasing 100011 . This genocode is the basis of the largest power in the world, uniting boundless Eurasian spaces. The similarity of the genocodes of Russia and the Balkan states is due to their common cultural roots: the influence of Byzantium, from which these states adopted Orthodoxy, and the TurkicMongolian empires, which influenced their state-political structure. Recall that the Balkans for about five hundred years were part of the Ottoman Empire, and for several centuries Russia was in vassalage dependence on the Golden Horde.

The transitive genocode of Greece is called Bite-Polarizing 100/110 101. This conflict genocode was formed as a result of the location of Greece between two warring cultures: European Christian civilization and Asian Islamic ones. For more than 400 years, Greece was part of the Ottoman Empire, its eth- 
nic composition fueled by settlers from the Middle East and Africa. Therefore, the birthplace of European civilization has become a collectivist country with a high distance of power, which for a long time was ruled by authoritarian regimes. And now Greece does not fit well into the concert of the European Union and its exit from EU is constantly on the agenda.

Turkish transitional genocode $\mathrm{Di}$ minishing-Nourishing 110 001-100 001 acts as an intermediary between the national cultures of the Kingdoms of Dui and Zhen. It is essentially the buffer genocode. The Greek geopolitician Dimitros Katsikis in the concept of the Intermediate Region, linking East and West, expressed this function of the Turkish genocode [11]. But from the position of the NCG Turkey's accession to the EU is unlikely.

Bounded by rigid frameworks of the article, we could not analyze the interaction of genocodes. Note only, that the greatest conflicts are observed between individualistic and collectivist genes (for example, fierce wars between Germany, the kingdom of Lee, and Russia, the kingdom of Zhen), and within individual kingdoms - between male and female genocodes. Therefore, many years of bloody wars between France (the yin-gene of femininity) and Germany and England (the yang-gene of masculinity) receive their new coverage.

Conclusion. The concept of NCG unites Hegel's theory of national spirits, cross-cultural measurements of national cultures and the system of archetypes of collective unconscious in a single whole. This synthesis of philosophy, sociology, culturology and symbolism has a great cognitive potential. Even from this very general overview, the interdisciplinary concept of the NCG makes it possible to understand place and function of some European peoples in the European community. This is very important for building long-term forecasts.

But the NCG is a static, structuralfunctional concept. Therefore, it should be complemented by an evolutionary concept, a concept of the historical development of European civilization based on the system of its cultural archetypes.

\section{REFERENCES}

1. Patrakov V.P. Geopolitics of the Book of Changes. Time of the Eurasian meridian. - Moscow-Berlin : Direct Media, 2015. - $441 \mathrm{p}$.

2. Patrakov V. P. Genocodes of national cultures. Conceptual bases // Public Administrative, 2016, available at: https://cyberleninka.ru/article/n/ genokody-natsionalnyh-kultur-kontseptualnye-osnovy

3. Hegel G. W. F. Philosophy of Mind // Encyclopedia of Philosophical Sciences. V. 3. - M. : Mysl', 1977. - 471 p.

4. Hegel G. W. F. Element of the Philosophy of Right. - M. : Mysl', 1977. $524 \mathrm{p}$.

5. Mills Jon. The unconscious abyss : Hegel's anticipation of psychoanalysis. - State University of New York, 2002. $-261 \mathrm{p}$.

6. Hofstede's cultural dimensions theory, available at: https://en.wikipedia. org/wiki/Hofstede\%27s_cultural_dimensions_theory

7. Hofstede G., Hofstede G.J., Minkov M. Cultures and Organizations: Software of the Mind. - McGraw-Hill, 2010. $576 \mathrm{p}$.

8. Secter Mondo. The Architectonics Of Culture. A Critique, Modification, 
and Extension of Hofstede's Study of Societal Culture. - Simon Fraser University, 2003. - 346 p.

9. Jung, Carl Gustav. Differences between Eastern and Western thinking, available at: http://www.jungland.ru/ node/1811

10. Wilhelm Richard. The I Ching or Book of Changes. Translated from German to English by Cary Baynes. Princeton University Press, 1967. $730 \mathrm{p}$.

11. Intermediate Region, available at: https://en.wikipedia.org/wiki/Intermediate_Region

\section{СПИСОК ВИКОРИСТАНИХ ДЖЕРЕЛ}

1. Патраков В. П. Геополитика "Книги перемен”. Время Евразийского меридиана / В. П. Патраков. - Москва; Берлин : Директ-Медиа, 2015. $441 \mathrm{c}$.

2. Патраков В. П. Генокоды национальных культур. Концептуальные основы [Электронный ресурс] / В. П. Патраков // Публічне урядування. - 2016. - Режим доступа: https://cyberleninka.ru/article/n/ genokody-natsionalnyh-kulturkontseptualnye-osnovy

3. Гегель Г. В. Ф. Энциклопедия философских наук : Т. 3. Философия духа / Г. В. Ф. Гегель. - М. : Мысль, 1977. - $471 \mathrm{c}$.

4. Гегель Г. В. Ф. Философия права / Г. В. Ф. Гегель. - М. : Мысль, 1990. -524 c.

5. Mills Jon. The unconscious abyss : Hegel's anticipation of psychoanalysis / Jon Mills. - New York : State University of New York, 2002. - 261 p.

6. Hofstede's cultural dimensions theory, available at: https://en.wikipedia.org/ wiki/Hofstede\%27s_cultural_dimensions_theory

7. Hofstede G. Cultures and Organizations: Software of the Mind / G. Hofstede, G. J. Hofstede, M. Minkov. McGraw-Hill, 2010. - 576 p.

8. Secter Mondo. The Architectonics of Culture. A Critique, Modification, and Extension of Hofstede's Study of Societal Culture / Mondo Secter. - Simon Fraser University, 2003. - 346 p.

9. Юнг К. Г. Различия между восточным и западным мышлением [Электронный ресурс] / К. Г. Юнг. - Peжим доступа: http://www.jungland. $\mathrm{ru} /$ node/1811

10. Щуикий Ю. К. Китайская классическая "Книга перемен” / Ю. К. Щуцкий. - М. : Наука, 1993. - 606 с.

11. Кищикас Д. Геополитика Греции и промежуточный регион [Электронный ресурс] / Д. Кицикас. - Peжим доступа: http://evrazia.org/ article/1861 